\title{
AC 2011-2431: TEAM TEACHING THAT GOES THE DISTANCE: TEAM INSTRUCTION FOR A BROADCAST INTRODUCTORY ENGINEERING COURSE
}

\author{
Angela Minichiello, Utah State University
}

Angela (Angie) Minichiello, Principal Lecturer in the Department of Engineering and Technology Education at Utah State University, instructs core engineering courses at the Brigham City Regional Campus. Angie is a registered professional mechanical engineer and has over 15 years industry experience as a practicing engineer. She holds a BSME degree from the United States Military Academy at West Point and a MSME degree from Georgia Tech. Her research interests include adult learning theory, blended learning techniques, and improved methods for technology based instruction. She is a member of ASEE, ASME, and IEEE.

\section{Tracy D Blake, Utah State University}

Tracy Blake, a lecturer in the Engineering and Technology Dept. at Utah State University, instructs engineering courses at the Tooele regional campus. His industry experience covers a variety of fields including component and system level design. He has several years of teaching experience in electrical engineering at Arizona and Utah State Universities. His current position involves assisting in the building of an educational program that will allow students to take engineering courses at locations remote to the main campus.

\section{Wade H Goodridge, Utah State University}

Dr. Wade Goodridge, Principal Lecturer in the Department of Engineering and Technology Education at Utah State University instructs Solid Modeling, CAD, Introductory Electronics, Surveying, and Introductory Engineering courses at the Brigham City Regional Campus. Wade has has been teaching for the Utah State college of Engineering for over 8 years. He holds duel B.S degrees in Industrial Technology Education and Civil Engineering from Utah State University, as well as an M.S. and Ph.D. in Civil Engineering from Utah State University. His research interests include metacognitive processes and strategies involved in engineering design using Solid Modeling, learning style impacts upon hybrid synchronous broadcast engineering education, and team teaching in broadcast environments.

\section{David D. Sam, Ph.D., Utah State University}

Dr. David Sam, Principal Lecturer in the Department of Engineering and Technology Education at Utah State University instructs Materials Science, Manufacturing Processes, and General College Physics courses at the Uintah Basin Regional Campus. David has been with Utah State University for 2 years. Prior to joining the faculty at USU, he was a technical staff member at The Lawrence Livermore National Laboratory for over 20 years. He holds B.S. and M.S. degrees in Mechanical Engineering from Brigham Young University, and M.S. and Ph.D. degrees in Applied Science from Yale University. His current position involves building and improving distance education programs in the area of engineering science. 


\title{
Team Teaching That Goes the Distance: Team Instruction for a Broadcast Introductory Engineering Course
}

\begin{abstract}
The efficacy of team teaching, known also as co-teaching or collaborative teaching, as an instructional strategy is well established in the education literature $1,2,3,4,5,6$. Despite its proven legitimacy, mixed feelings concerning its practice persist: the mere mention of "team teaching" can summon a range of images, from collaborative, collegial nirvana to a "who's-in-charge?" edged chaos. For the better, team teaching has been compared to a "...semester long jam session" with instructors who "... share a deep love for the material..."2. For the worse it has created confusion and contention rather than brought clarity. Many agree that the elusive key to a co-taught success stems from the just right combination of topic and team: a topic of multi- or inter-disciplinary appeal combined with a team of instructors who share mutual respect, an interest in expanding viewpoints within their own disciplines, and a openness to risk-taking in their classrooms ${ }^{2,3}$.

This paper explores the use of an adapted team teaching approach, team-at-a-distance teaching, as an effective instructional strategy when put to practice for pre-professional engineering courses within a regional campus framework. With this newer twist on team teaching pedagogy, a multi-disciplinary instructor team is geographically dispersed with students that interact through a broadcast delivery system. Thus, an instructional platform is created to mimic the student learning environment and promote desired student outcomes.
\end{abstract}

This approach is developed for delivery of an introductory engineering course. The course, Introduction to Engineering Design, is delivered via Interactive Video Conferencing (IVC) synchronously to students located at four regional sites throughout the state by the preengineering faculty team. The instructional team consists of four engineering faculty who share the overall responsibility for development and delivery of the regional campus pre-engineering program. Introduction to Engineering Design is a two credit course taught every Fall semester that, for pre-engineering students, fulfills the introductory engineering course requirement for every engineering discipline within the College of Engineering $(\mathrm{CoE})$.

In developing the instructional platform, the faculty team identified four guiding tenets of the course:

- Promote the Pre-Engineering Program: To fulfill introductory course requirements of all departments within the CoE using the combined expertise of a multidisciplinary instructional team. 
- Promote Distance Delivery of Engineering Education: To engage remote students in a distance delivered framework with a geographically dispersed instructional team.

- Promote Engineering Professionalism: To educate students in the profession of engineering and engineering ethics by highlighting the experiences of a multidisciplinary instructional team and practicing engineers as invited speakers.

- Promote Engineering Recruitment and Retention: To excite students to complete engineering degrees and join the engineering profession with a learner-centered instructional environment.

Based on the desired outcomes, instructors improvised the team at a distance-teaching approach to reflect the primary tenets of the course: 1) each instructor represents a unique engineering discipline and collectively the team provides a foundation for a broad introductory curriculum, 2) each instructor is physically located at a different regional campus, mimicking the geographical dispersion of students and supporting student learning and engagement, and 3) together, the interplay of the multi-disciplinary, geographically dispersed instructor team realistically depicts today's engineering workplace and promotes the field as a viable, meaningful career choice through open discussion and learner discovery. Results from student course evaluations and surveys, and instructor reflections are used to comment on and assess the basic effectiveness of the instructional approach.

\section{Team Teaching as Pedagogy}

Team teaching originated as pedagogy in 1963 when William Alexander, "Father of the American middle school", proposed a concept of grouping teachers into teams to educate students groups as a means for junior high school reform. The perceived benefits of team teaching, namely the creation of a supportive, inclusive environment for students and the necessity for teaming teachers to formally engage one another in planning, integration, evaluation, and reflection, have helped promote its use across K-12 and into higher education ${ }^{7}$.

Team teaching is collaborative teaching. For all of its many benefits, teaching collaboratively requires much above and beyond what is required if one is teaching solo. A true co-taught course is integration come to life: from the interdisciplinary nature of its subject matter to the teambased delivery of its lessons. As noted by Schlosberg and Sisk, true team teaching is not commensurate with "...the oft-used model of 'tag-team-teaching,' where instructors alternate

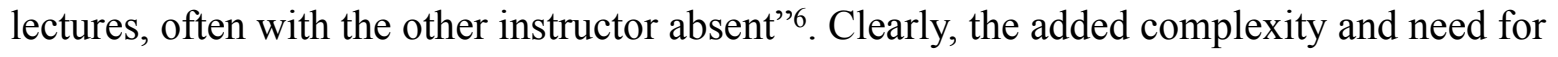
coordination that ensues deters many from attempting a team taught course, perhaps most often in higher education. Several team teaching show-stoppers for university courses are documented in the literature including: questions of credit for teaching loads, dueling egos, collegial competitiveness, lack of precedent, lack of administrative incentives, logistic and scheduling issues, and cost ${ }^{3,4,6}$. A noteworthy and illuminating look at the so-called rules of effective 
collaborative teaching in higher education is presented in the "Ten Commandments of Team Teaching" 8 .

Team teaching is well-founded in the higher education literature. Our interest in this article is to qualitatively assess the use of a team teaching strategy to promote engineering education student outcomes in distance education environments, namely for courses taught via broadcast delivery to non-traditional student audiences. While a review of literature reveals that team teaching is historically applied in fields of social sciences and humanities, several sources document its application to create "custom" interdisciplinary courses that combine engineering with other fields, namely business, mathematics, and the natural sciences ${ }^{3,9,10}$. New emphasis on learner centered strategies for improved Science, Technology, Engineering and Mathematics (STEM) instruction $^{10,11}$ is reflected in recent articles documenting the use of multi- and inter-disciplinary instructor teams to enhance introductory and capstone undergraduate engineering course outcomes $12,13,14$. The largest instructor team (15 instructors) noted was used to teach an multidisciplinary course in advanced building design to senior engineering students ${ }^{15}$.

Evidence of use of team teaching pedagogy in synchronous and asynchronous distance education is documented. In the case of synchronous delivery, video conferencing was used across five campuses in Wisconsin to deliver a course in Early Childhood and Special Education ${ }^{16}$. The authors noted the added cultural and linguistic diversity brought to the classroom by synchronously linking regional campus sites. A blended synchronous model was proposed for international educational collaboration ${ }^{17}$. The proposed model reflects the synchronous regional campus instructional paradigm described in this article. The authors' maintain that today's educators must engage in collaborative efforts using web-based technologies in order to retain competitiveness in an increasingly digital work and market place. Finally, team teaching via synchronous interactive video conferencing was used to present a course on nuclear power plant operations between two universities in Ohio ${ }^{18}$. The authors note that traditional teacher -centered presentations (lectures) are "particularly unengaging" for remote students and variations in teaching approaches are needed to actively involve students in a distance learning environment. Stated use of a team teaching strategy for improving non-traditional student outcomes was found ${ }^{3}$, although it did not occur in a distance learning environment.

\section{Associate in Pre-Engineering Degree Program: A Regional Pathway to Engineering Education}

In response to requests from Utah-based industry for qualified engineers and to meet the needs of working professionals in rural Utah communities, Utah State University (USU) began its Associates in Pre-Engineering Degree program in January 2009. This two-year degree program allows students to complete general education and pre-professional (freshman and sophomore level) engineering course requirements at multiple regional campuses located throughout the state. In this way, regional campus students can fulfill all of the requirements of the first two years of an engineering bachelor's degree without disrupting their work schedules, traveling, or relocating. Relocation can be delayed until students' junior-senior years when they enter the 
professional engineering program and complete their course of study at the main university campus in Logan.

While the overriding purpose of the degree is to provide a pathway to a traditional four year engineering degree for Utah's non-traditional students, all students completing the Associates in Pre-Engineering degree are prepared for advanced careers as technicians and technologists within their chosen disciplines. Since its inception at the Brigham City regional campus in 2009, the Pre-Engineering program has expanded to the Uintah Basin and Tooele regional campuses. The recent merger of USU with the College of Eastern Utah (CEU) will expand the program to southeastern Utah.

The USU Department of Engineering and Technology Education (ETE), housed in the College of Engineering $(\mathrm{CoE})$ and located in Logan, administers the program and employs program faculty. The Pre-Engineering program instructional model takes advantage of the expertise of the engineering faculty at each regional site, as courses are taught by faculty based upon their engineering expertise. Courses are synchronously broadcast via interactive video conferencing to students at the other participating regional campuses.

Students enrolled in the Pre-Engineering program can complete all of the required preprofessional courses for the bachelors degrees offered at USU including electrical, computer, mechanical, civil, environmental, and biological engineering.

\section{A Regional Student Audience: Catalyst for Change}

The words of USU President Stan Albrecht, “...We are 'one university, geographically dispersed' maximizing access to students of all ages and situations..."19 set the tone and standard for the regional campus Pre-Engineering program. With the advent of the regional campus system, we welcome in a new, non-traditional student body. As 'one university', it is our charter to educate, advise, and mentor the regional student body to the same standard and with the same rigor as is done in Logan.

As faculty of the Pre-Engineering program, we take this charter seriously. We work closely with Logan campus faculty and administrators to insure regional campus classes provide the same focus of content and require the same level of achievement as do counterpart classes in Logan. After all, we are preparing regional students to join the larger university engineering cohort in their junior year and transition to academic life in Logan.

Thus, our initial thought concerning how to teach Introduction to Engineering Design at the regional campuses was to duplicate what was currently being done. The curriculum had been developed for a 2003-2004 USU CoE study ${ }^{20}$ that considered how the freshman introductory engineering experience affects retention. The curriculum is primarily intended for engineering students who have not yet selected a specific engineering major, students from other disciplines who are considering engineering, and pre-engineering students who are not calculus-ready ${ }^{20}$. The course provides a basic understanding of the engineering profession, engineering specialties, 
problem solving, computer tools, teamwork, communication, design and ethics using a standard textbook ${ }^{21}$ as general reference and several hands-on laboratory experiences. The principle pedagogy employed for the laboratory portion of the course is a modified jigsaw approach to cooperative learning ${ }^{22}$. In this approach, the class is broken down into groups of four and each member takes turns learning a lesson from the instructor and then teaching it to the rest of their group. The group then completes a design based exercise on the lesson. Group scores are used as part of the overall student assessment. Because the modified jigsaw strategy requires that the instructor meet with only $1 / 4$ of the students for each laboratory lesson, hands-on experiences remain manageable even as the number of students exceeds 100 or more and the number of required lab stations is considerably reduced ${ }^{22}$.

In general, the purpose of the Introduction to Engineering Design course is to attract and retain freshman engineering students ${ }^{20,22}$. The current course was specifically designed to provide the typically large pre-engineering class sizes meaningful laboratory experiences deemed necessary to excite students to pursue careers in engineering. Significant state and private funding was used to purchase laboratory equipment and develop hands-on experiences around a common area of engineering and instructor expertise: computer simulation, data acquisition and control technology. Consistently over time, the students have been pleased with the cooperative learning aspects of the course.

In preparing for the regional campus course, we came to realize that course design is not a onesize fits all proposition. What works for one student audience may not work for another. Large student-to teacher ratios were not a regional campus issue, especially when we began to contemplate the multi-disciplinary benefits of involving more than one instructor in the course. We agreed that hand-ons experiences are beneficial, but were unsure that the current cooperative learning activities could be effectively reproduced for multiple regional audiences via distance technologies- especially since we did not have laboratories equipped with the required simulation, data acquisition and control equipment immediately available to all regional students. Furthermore, Pittsburgh Freshmen Engineering Attitude Survey (PFEAS) data collected during the 2003-2004 USU CoE study indicated that USU students did not consider a hands-on experience necessary to have a positive freshman engineering experience ${ }^{23}$.

We surmised that the demographics, needs, and interests of regional campus students may differ from those in Logan. We thought we may have a greater percentage of students who are "shopping" to see what engineering is all about or if it may be for them. We didn't want to disinterest students with activities that were singly focused in one area of engineering. Based upon regional industries throughout Utah, we expected many students to be interested in civil and petroleum engineering careers. Our students would most likely be older with full-time careers and life experience. We wanted to make use of their experiences and bring them into the classroom. We knew we couldn't expect much time for coordinated, synchronous student interaction outside of class time (during normal work hours) since most of our students are employed during the day. Student interaction outside of class, if any, would most likely occur asynchronously online. We wanted to include a component of the course that aides regional 
campus students in understanding the academic advising process and engineering major requirements. Finally, we felt it important to our retention goals to devote some time to preparing regional students for academic life on main campus through introduction to the use of the library and online library resources, writing center, and popular university clubs that appeal to engineers (e.g. Engineers without Borders).

Thus, we decided to improvise on the current course, retaining the majority of content and textbook and striving to bring in multi-disciplinary activities (paper based or hands-on) into the distance setting. While we decided to forgo the cooperative learning piece; we agreed instead to play to our perceived strong suit: a multi-disciplinary team of instructors willing to collaboratively teach the course in order to get the Pre-Engineering program off and running.

\section{Team-at-a-Distance Teaching as Andragogy}

Our improvisation lead us to the team-at-a-distance teaching model, in which the regional instructor faculty co-teaches the course that is synchronously broadcast via interactive video conferencing. The first year the course was taught (Fall 2009) three instructors [Goodridge (civil) and Minichiello (mechanical) at the Brigham City campus and Sam (mechanical and engineering sciences) alternately at the Vernal and Roosevelt sites, which collectively comprise the Uintah Basin campus] and two regional campuses (Brigham City and Uintah Basin) participated. The second time it was taught (Fall 2010) four instructors (Blake (electrical) at the Tooele campus, Goodridge and Minichiello at the Brigham City campus and Sam at the Uintah Basin campus) and three regional campuses (Brigham City, Uintah Basin, and Tooele) participated.

In our modified team teaching model, each instructor participates in the planning, organizing, delivering, and evaluating the course progress and student outcomes. Instructors use email, voicemail, and video conferencing to plan and coordinate. All instructors generally attend every class and, while lectures and discussion are typically presented singly by one instructor, all instructors are engaged and offer feedback and viewpoints on the discussion topics. Teaching credit is alternately given to each instructor every four years. Each semester, the instructor who is given the teaching credit is designated as the "lead organizer" of the course for that semester. This instructor updates the syllabus and proposes the schedule and assignments of lectures and lab work, schedules invited speakers, maintains the website, proposes a culminating course project, and generally tends to the administrative issues of the course. If there is a question of judgement during the course that cannot be reached by consensus, this instructor makes the final decision. All in all, it is fair to say each instructor makes a conscious effort to follow the "Ten Commandments of Team Teaching" 8 most of the time.

In retrospect, after delivering this course for two semesters, team-at-a-distance teaching is proving an effective method for creating a learner-centered environment, commensurate with the needs of adult learners. According to Malcolm Knowles, both the role of learners' experiences and learners' orientation to learning are core principles of andragogy: the art and science of teaching adults. Adult learners accumulate a wealth of life experiences that serve as important 
resources for learning. Adult learners learn effectively when experiential learning techniques, such as group discussion, simulation exercises, case studies and problem solving, are employed instead of one-way transmission of information from instructor to student. Furthermore, in contrast to the subject-centered orientation typical of pedagogy (the art and science of teaching children), adults learn most effectively when information is presented in real-life situational contexts ${ }^{24}$.

With team teaching, the role of any single instructor is diminished and, as a result, the learning environment is intrinsically more learner-centered. Instructors who teach collaboratively invite discussion and comments from not only students but peer instructors who not always agree and may have conflicting viewpoints. There is no one source for information, no ultimate content authority. With the allowance for more sources of information (because there is more than one instructor) students feel more comfortable sharing their thought and experiences: their knowledge and personal experience is elevated and considered relevant information to the course. Thus, team-at-a-distance teaching supports experiential learning techniques and more effectively incorporates the knowledge and life lessons provided by the non-traditional students into the content of the course.

In a distance broadcast learning environment, the team-at-a-distance approach further supports a learner centered environment and diffuses impressions of hierarchy that can arise between "originating" and "receiving" or "satellite" sites. With an instructor(s) present at each participating site (each regional campus), all sites enjoy a perception of equal importance and stature, and a mutual sense of support. Periodically throughout the course, all sites, at times, will be originating and, at other times, will be receiving. Additionally, having an instructor at each site (campus) insures that all students have the same access to face to face counseling and assistance if required. Providing student access to one-on-one help instructor assistance is a critical component important for any course where retention is important.

\section{Curriculum Put to Practice at the Regional Campuses}

Introduction to Engineering Design is a two credit hour course taught in two hour segments one evening each week for a full academic semester. A major portion of the course is the material presented from the textbook Engineering Your Future by William Oakes ${ }^{21}$. The text covers basic albeit important information for understanding the profession of engineering including: the history of engineering, engineering specialties, problem solving, computer tools, teamwork, communication, design and ethics. Material from the text is augmented with group discussions led by the team of instructors (all of whom are engineers), invited speakers (practicing engineers from the regional communities), speakers from university groups that can help regional students prepare for academics on main campus (academic advisors, librarian, student representatives of engineering related clubs), hands-on exercises (laboratory exercises and homework related to the text), an oral presentation project (the five-minute engineer), and a culminating end of course research project (paper) on a current critical event of engineering importance. 


\section{Textbook Material}

Students are assigned readings by chapters. Pre-class multiple choice quizzes are posted on the course management website (Blackboard). Students must complete the quizzes online prior to coming to class on the day the chapter is assigned. Quizzes insure the reading is completed to promote a good class discussion. Since the quizzes are automatically graded in Blackboard and scores are available prior to class, they provide the instructor insight into topics that require emphasis or clarification during the discussion.

\section{Class Discussions}

On a rotating basis (almost) every week, instructors lead a one hour (approx) discussion or facilitate an exercise concerning the assigned textbook material in order to deepen student understanding, highlight student and instructor experiences, answer questions, and allow for student feedback.

\section{$\underline{\text { Homework Exercises }}$}

At the completion of a chapter discussion or activity, the presenting instructor assigns a homework assignment that involves the material from the chapter for that week. The assignment is due at the next class period and the instructor who assigns the homework is responsible for grading it. For turn in, homework is typically uploaded to the Blackboard website or emailed to the instructor.

\section{Engineering Speakers}

On a bi-weekly basis, current practicing engineers are scheduled to come to class and present a one hour (approx) presentation on their engineering discipline, background, and experiences as an engineer. Engineering speakers that have presented in the course represent a variety of engineering specialities (mechanical, civil, electrical, petroleum, environmental, biological), come from the local communities that the regional campuses serve, and are typically USU graduates (for at least one of their degrees). We focus on hosting practicing, professional engineers instead of engineering professors for these presentations because one of our goals for the course is to excite students to join the profession of engineering, not necessarily engineering academia.

\section{$\underline{\text { University Speakers }}$}

At strategic times during the semester, university speakers are invited to class to present important "tricks of the trade" type information to the regional campus students. In these presentations, our goal is to bring the regional students "up to speed" on tools, activities, and that may be beneficial to them as they pursue their engineering studies. Examples of previous university speakers for the course have been: the regional campus engineering academic advisor 
to discuss how to choose engineering as a major and set up an engineering program of study, the university engineering research librarian to discuss regional campus online access to the university library and tips on conducting library research for the end of course project, student club officers for Engineers without Borders, a club based on main campus, and the regional campus engineering club.

\section{Laboratory Exercises}

On a bi-weekly basis, course instructors take turns presenting a structured "laboratory" experience for (approx) one hour. Each experience covers a distinct engineering-related topic and is chosen mainly by instructor interest. Typically, instructors choose a topic or demonstrate a skill that will be useful to the students as they continue their engineering studies and careers. Additionally, instructors try to vary the nature of the labs to introduce students to an array of engineering disciplines. The laboratory experience may be hands-on or it may be calculation based. At the conclusion of the experience, the instructor assigns a take home activity for the students to complete and turn in within 1-2 weeks. Depending upon the nature of the activity, the assignments may be turned in electronically and graded by the presenting instructor or they may be graded by the local instructor at each site. In any event, the presenting instructor is responsible for creating a grading key and resolving any grading discrepancies. Examples of laboratory experiences we have used in the course are:

- Use of the solver function in Excel

- Use of a graphical digitizer to produce discrete data and then plot data in Excel

- Force-acceleration data collection experiment using fan powered carts

- Simple static truss analysis

- Use of Excel to complete a beam design

- Calculation of binary numbers

- Simple network analysis with an introduction to PSpice

\section{Oral Presentations}

Students are informed about the "Five-Minute Engineer" oral presentation assignment at the beginning of the semester. The Five-Minuter-Engineer is a five-minute oral presentation with training aide given by each student to the class over the interactive video conferencing system. The presentations are given on an engineering topic of student choice and occur toward the end of the semester so that students have adequate time to focus their topic (instructor approval required), develop their training aide, and practice their presentation. The Five-Minute Engineer assignment was derived from the One-Minute Engineer $(\mathrm{OME})^{25}$ presentation concept developed at Ohio Northern University.

The Five-Minute Engineer experience is designed to give students exposure in developing a short technical presentation and delivering it to a remote audience over a technology based communication system. As engineers, clear and precise communication is critically important. 
Moreover, we engineers find ourselves more frequently working in geographically dispersed teams that need to communicate via technological means (email, chat, video, etc). Unlike OME presentations, students giving Five-Minute Engineer presentations are required to have a presentation aide (demo, slide set, etc) in order to adequately communicate technical material via the broadcast system. The Five-Minute Engineer presentations are graded largely upon effort and timely completion. However, the RSVP rubric ${ }^{25}$ is used to provide both instructor and peer feedback to the each speaker so that students can use the experience to improve their presentation skills.

\section{$\underline{\text { Research Project }}$}

A library research final paper is assigned midway through the course to be turned in during final exam week. The paper is on an assigned topic of current interest and related to the engineering profession. The 2009 topic was water shortages in the western United States and the 2010 topic was the Deepwater Horizon Oil Spill that occurred in the Gulf of Mexico. A broad topic is assigned to the class as a whole and then each student, with instructor approval, is required to focus to a narrower subtopic in order to complete the required five page research paper. Use of the university library online research tools is required as are a minimum number of sources. A university librarian is brought in as a guest speaker (over the video conference system) a few times throughout the semester to introduce the regional students to the library and the online tools for finding and retrieving source materials. Additionally, the librarian constructs an online resource called a "libguide" for the course. Libguides are custom websites created by USU librarians to link resources and tools for performing online library searches within the USU system for a specific topic or course in one location. The libguide for this course (http:// libguides.usu.edu/engr1000) is updated each time we teach the course.

Final research papers are due during finals week and carry a stiff penalty for lateness-due to obvious reasons. Papers are turned in electronically via Blackboard. A grading rubric that was established by the instructors and is updated each time the course is taught is used as the basis for assigning grades. To perform grading, the papers are equally divided among the instructors so that each instructor initially grades $1 / \mathrm{n}$ of the total number of papers, where " $\mathrm{n}$ " is the number of instructors. Instructors assign grades to their assigned papers using the rubric. A master rubric is created by the administrative lead instructor and it and the graded papers from the lead instructor are then passed via email to a 2nd instructor. The 2nd instructor reviews the papers, grades,and comments of the lead instructor and notes any discrepancies. Questions concerning assigned grades are resolved between the two instructors. The 2 nd instructor then adds their grades to the master rubric and sends it plus their papers with comments to the 3 rd instructor and so on. This process continues until the master rubric is sent back to the lead instructor. This process insures that all papers are reviewed by two instructors in order to maintain consistency in grading. Once the master rubric returns to the lead instructor, the lead calculates course grades. Course grades are reviewed by all instructors prior to submittal. 


\section{Student Feedback}

The course as described has been taught twice: once in the Fall of 2009 and once in the Fall of 2010. In Fall of 2009 there were three co-instructors (Goodridge, Minichiello and Sam) and 16 students across two regional campuses (Brigham City and Uintah Basin). The end-of-course student evaluation scores were 5.3 (BC students) and 4.9 (UB Students) out of 6 points for Overall Quality of the Course (OQC) and 5.8 (BC students) and 5.0 (UB students) out of 6 points for Instructor Effectiveness (IE). Overall mean scores for the CoE were 4.9 for OQC and 5.0 for IE that semester. The fact that scores were slightly higher in Brigham City, especially for instructor effectiveness, is thought to be a result of two instructors physically located at Brigham City compared to one across two sites in Uintah Basin. Interestingly, the highest ranked subtopics in the student evaluation were opportunity to ask questions and opportunity to comment and express opinions. These results are indicative of a classroom focus on the student and experiential learning which we propose are enhanced by the team-at-a-distance approach.

In the Fall of 2010 there were four co-instructors (Blake, Goodridge, Minichiello and Sam) and 15 students across three regional campuses (Tooele, Brigham City, and Uintah Basin). Unlike Fall 2009, the course was evaluated as a whole and scores were not detailed per regional campus. The end-of-course student evaluation scores were 5.3 out of 6 points for OQC and 5.3 out of 6 points for IE. Overall mean scores for the CoE were 5.0 for OQC and 5.0 for IE that semester.

Student course evaluation scores for the team-at-a-distance taught ENGR 1000 course compare favorably with those from for the more hands-on, laboratory intensive version of ENGR 1000 taught via face to face at the Logan campus. Student evaluation scores for the Logan ENGR 1000 class were 4.9 for OQC and 4.9 for IE for Fall 2008 (37 responses) and 5.2 for OQC and 5.3 for IE for Fall 2010 (15 responses). ENGR 1000 was not taught on Logan campus in Fall 2009.

A anonymous course survey was posted on Blackboard at the end of the 2010 semester course. Students were asked to complete it by providing their opinions on specific parts of the course. The purpose of the survey was to tease out feedback on specific aspects of the course, such as instructional strategy, oral presentation and research presentations assignments, that may or may be addressed on the end of course survey.

Possibly the most important information we got form the survey was a sense of how well the course met its foremost objective: engineering recruitment and retention. In the survey we posed the following two questions:

A. On a scale of 0 to 5, with 0 being not very interested and 5 being very interested, rate the your interest in the course subject: the profession of engineering. Please provide comments on what subjects and activities you found the most and least interesting. Please provide specifics wherever possible 


\section{B. Has your interest in the profession of engineering increased, stayed the same, or decreased due to taking this course? Please provide specifics concerning your answer.}

Responses to the questions, provided below, seem to suggest that overall the course is helping to attract and retain engineering students.

\section{Responses to Survey Questions A. and B.}

\section{Response 1}

A. 5-I really enjoyed this class, I took it to help me decide which engineering i wanted to go into.

B. My interest has increased due to taking this course. I was really interested in making engineering my major, and I figured out, that I want to go into mechanical engineering. :)

\section{Response 2}

A. 3 it was a good class but i really didnt learn as much as i thought $i$ would...

B. my interest is the same the class helped narrow down a little bit of what part of engineering i like the most

\section{Response 3}

A. 5 enjoyed the class

B. Stayed the same

\section{Response 4}

A. 5. I am very interested in the subject of engineering. I wasn't very familiar with any type of engineering until I took this class. All of the professors did a great job presenting many different types of engineering...

B. All I knew was that I had picked Civil Engineering as my career choice. I wasn't exactly sure of what that entailed. I am now more interested in that choice and I am more excited about my future.

\section{Response 5}

A. $i$ rate this calss at $4 \mathrm{i}$ thought it was an interesting class because we got to learn a little bit about every engineering degree.

B. its stayed about the same because i didnt really get to learn much about petroleum engineering because it showed a little of everything so i stayed about the same.

\section{Response 6}

A. 4. I really liked the labs and most of the speakers. I think the labs helped because they gave us some sort of idea what a career in engineering would be like.

B. I think it has stayed the same, but has given me a better idea of what engineers do, and has introduced me to other fields in engineering that $\mathrm{i}$ wasn't familiar with before. 


\section{Responses to Survey Questions A. and B.}

\section{Response 7}

A. had an intrest level of a 3 or 4 at the begining but it now has dropped to a 1 or 2 . i enjoyed the labs and some of the assignments but the lecture was my least favorite part.

B. it has decreased, you can refer back to question number one, that will also answer this question.

\section{Response 8}

A. 5 I enjoyed the lectures from the guest speakers. They opened my eyes to a myriad of opportunities in any given engineering field.

B. 5 [out of 5] it has increased. The experiences shared by other engineers is the most motivating aspect to pursue engineering.

\section{Response 9}

A. 5. Engineering is what I love to do. This class showed me what it really means to be an engineering. I loved how different engineering in different fields come in and talked to us. B. My interest in the profession of engineering has stayed about the same. IT is very high and something I really like. The class keep me on that path and did not drag me down.

\section{Response 10}

A. I was about a 4 I was intrested but i didnt know if $i$ wanted to deal with all the math. I found that I really liked the guest speakers they allowed you to get a better view of what it was like to work in the field.

B. It has increased a little I would like to find out more about the diffrent areas of engneering. Now that $\mathrm{i}$ have a little more of an idea on how to fix things.

\section{Response 11}

A. The least interesting for me was when we reviewed the chapters... I had already read them and found it just re-reading. The times where specific examples from the instructors were used it was better.

B. For me it has stayed the same, I am already in the field and just going back to get the degree to back up my experience... I would think for those who really are trying to decide it was very helpful to get them vested or not. The open honest discussions around what it takes, how hard you will have to work once you graduate and the money you really make were priceless for those decisions...

\section{Response 12}

A. 5. I think that this course was great to help a student figure out where they want to go. I am surprized that it is a required class for the ones of us that know which way we want to head. ..

B. My intrests have not changed becasue of the class.

\section{Response 13}
A. 3
B. 4 


\section{Responses to Survey Questions A. and B.}

\section{Response 14}

A. 5 on the applications of engineering. 3 on the lectures from the book. 4 on the guest speakers we had.

B. It is the same. I haven't learned anything that could have provided me with a better or worse view of it.

Representative students comments from the 2009 and 2010 end-of-course evaluations and the 2010 survey concerning specific areas of interest for the course are provided below.

\section{Team-at-a-Distance Teaching Approach}

- I enjoyed the opportunity to learn from all three instructors. (2009)

- Having three instructors was cool. (2009)

- Good diversity for all of the disciplines. (2009)

- I enjoyed the assignments in the class, instruction was awesome. (2009)

- The instruction was awesome. (2010)

- We have alot of teachers which helps with learning. (2010)

- I liked that there were different varieties of [engineering] instructors teaching the class. (2010)

- Having 4 professors was hard to get used to, at times I felt like different instructors had different expectations. (2010)

- Having the class shared by professors from different backgrounds was great. (2010)

- Class [should] have better equipment for broadcast [delivery] system. (2010)

- The communication between teachers and students [could be improved]. (2010)

- I really enjoyed having the different aspects of engineering available. It really helped me, I was taking this class to help me decide which field of engineering I wanted to go into. (Survey)

- I love that we had access to real life experience and multiple perspectives. Now if it is worth it to the school or not to pay for all of you I do not know but certainly I would rate it as a key contributor to the success of the class and hope it continues. (Survey) 
- If we were perhaps doing serious applications of engineering this method might be effective but as it was with freshman students who haven't learned any of the finer points, having four teachers was a bit much. (Survey)

- Had a lot of fun for a late night course! the class was interesting and kept my interest. (Survey)

\section{$\underline{\text { Course Content }}$}

- It was a very good introductory course that allowed me to choose a specific major. (2009)

- Some of the material was a little advanced for the course. (2009)

- I think that some more detail about the different fields would be good. (2009)

- It would be helpful if it wasn't so repetitive. (2010)

- The challenge of learning new material as it relates to engineering [was especially good]. (2010)

\section{$\underline{\text { Laboratory Exercises }}$}

- I enjoyed the lab work. (2009)

- The labs were the content of this course that I felt were especially good. (2009)

- I liked the labs alot, it was nice to apply some things from the engineering field. (2010)

- Being able to use excel [was especially good]. (2010)

- [More] labs, but that means more money. (2010)

\section{Engineering Speakers}

- I like many of the guest speakers. (2009)

- Having speakers was the content of this course that I felt were especially good. (2009)

- I enjoy the guest speakers. (2010)

- The guest speakers and emphasis on the real world and what it takes to become an engineer [were especially good]. (2010) 


\section{Oral Presentation}

- The oral presentation is fun because it gets everyone involved and seeing each other. ..[more of these types of activities] would make it a lot more interactive and it would provide the students with and "invested interest" in the other class mates success. (Survey)

- The oral presentation was a great blend of low stress, but still very interesting and educational. I really liked it. (Survey)

- I did like the five min. presentation at the end of the course. The fact that it was so short made it fairly stress free and I really enjoyed seeing all of the other different presentations. There were so many different types of presentations on engineering and I thought it was great. (Survey)

\section{$\underline{\text { Research Paper }}$}

- The research paper was also very good. The subject was assigned and I was able to learn much about that particular subject. (Survey)

\section{Faculty Reflection}

The four faculty were asked to reflect about the course and its effectiveness at meeting desired student outcomes. Faculty comments grouped by topic are provided.

\section{Team-at-a-Distance Teaching Approach}

- I think the class pedagogy is working effectively to introduce students into the variety of engineering disciplines. I think it has been very advantageous to allow students to learn from four different instructors each with a different emphasis in engineering.

- The team teaching approach gives the students [access] to different faculty with diverse backgrounds, thus helping students to better view the different disciplines within engineering.

- There is value in different faculty sharing their experiences within their specific discipline. There has been positive feedback from students regarding the team teaching approach to this class.

- I thoroughly enjoy instructing this course as a team taught course with other engineers of varying backgrounds. After teaching the course in this manner, I would be very hesitant to try to teach it solo! There are just so many more ideas and experiences that come up with coteaching. 
- Maintaining student engagement is difficult over broadcast technology, especially in the late evening hours! I think the team-at-distance approach greatly improves our student interaction and engagement while using the broadcast system.

- Managing the administrative aspects of the course can be difficult with four instructors who are located at different regional campuses. We really rely on instructor enthusiasm for the course and professionalism to insure that all members stay involved and communicating.

- Offering a course such as this requires commitment on the part of the administration. Our administration supports the use of instructor time in this manner, largely because the course is seen as a means for recruitment and retention of students in the fledgling pre-engineering program.

- Students can easily become confused about who to turn an assignment into or how to turn it in. Best to establish common practices in the beginning and stick to them.

\section{$\underline{\text { Course content }}$}

- The material presented as outlined in the textbook provided valuable information to help students succeed in the rigors of engineering majors.

- The text is excellent- enjoyable to read, current, and well organized. I think it serves as an excellent framework for the course. It serves as a good resource for students to refer back to.

- Blackboard based quizzes definitely encouraged reading of class material.

- The course should have had more of a design component. Some assignments should have been focused on solving a problem using the "Engineering Design Process".

\section{Engineering Speakers}

- I think that it has been well worthwhile to allow engineering professionals to come to class to show students what their work is like.

- Guest lecturers give students further knowledge regarding the various engineering disciplines and show them the diversity of work that is available within engineering careers.

- The invited lectures by practicing engineers are a critical part of the course. They focus course emphasis on the engineering profession as opposed to academe. They serve as examples of local individuals and USU graduates who have found meaningful careers in engineering. The invited engineering speakers also act as contacts for professional networking for the regional campus students. 


\section{University Speakers}

- I like this piece. Speakers from the university help to acclimate regional campus students to the opportunities available on the main campus. I hope it makes them feel more apart of 'one university'.

- Having the regional campus engineering advisor speak to the students was very beneficial. Many students at locations other than Logan (where she is located) were able to connect with her and get their programs of study set and their questions answered. If students decided they want to pursue engineering during the course, they now exactly who to contact... and how!

- Bringing speakers in from the main campus not only educates regional campus students about what is going on on main campus, but also helps to establish what is going on at the regional campus with a larger main campus audience. Such interaction can only help to strengthens the Pre-Engineering program.

- [I think a pro of the course was] having a librarian discuss resources at the USU library. This gave a much more thorough introduction to these resources.

\section{Distance Delivery / Broadcast Technology}

- The ability of the students to interact through the broadcast medium, while not ideal, is allowing opportunities to be established to those who may not have had them otherwise.

- Technology will always have glitches and broadcast technology is no exception. While it is amazing what we can do with it it is nevertheless very disappointing to have a problem with the software or hardware causing students or instructor to miss or not be able to take advantage of full class time.

- Grading can be a bit problematic with the potential of dropped emails, lack of student understanding on how to work with the technology, etc.

- Distance delivery of the course makes the hands-on piece harder to implement. In my opinion, providing hands-on experiences to students via distance delivery is the area of the course that needs the most improvement.

\section{Oral Presentations}

- The oral presentations were well extremely received by the students. I saw a distinct enthusiasm while they refined their topics and honed their presentations. It was a great way to incorporate experiential learning into the course. The exposure to technical presentation via broadcast technology was valuable. 
- Give at least two [oral] assignments so students can employ criticism from grading comments on the first assignment.

\section{$\underline{\text { Research Project }}$}

- Written communication and library research are important skills for engineering professionals. I like to present a current topic of importance to the engineering profession and have the students wrestle with it. I think it is a thought provoking way to wrap up the course.

- I think that how to access university library resources remotely to complete a research project is an important skill to teach engineering freshman.

- ... I believe that it would be useful to consider ... having the student work in groups and complete a project ... Such an approach would give the students valuable experience that they could apply perhaps in their capstone projects later in their academic career. The group experience is also valuable due to the engineering project teams methods employed within the engineering field. Perhaps projects such as this could replace the research paper that we have had the students complete in the past. The end product of the project would be a formal report.

\section{Conclusions}

It has been said that one of the greatest benefits of team teaching is "...the opportunity and necessity of becoming a reflective teacher."4 Issues of pedagogy (and andragogy), delivery, and style are much more (at times painfully) obvious when one teaches amidst peers as compared to when one teaches alone. In our efforts to become more scholarly in our teaching, the team-at-adistance teaching experience has demanded that we critically reflect on our instructional methods, our students' outcomes, and feedback from our students and peers. For this reason, alone, our team-at-a-distance teaching strategy is worth pursuing.

Clearly, teaching is not a one size fits all proposition; team teaching is not applicable in all situations. Why do we conclude that it works in ours? We can point to a few concrete reasons:

1. Course delivery via distance technology (remote audiences)

2. Non-traditional student audiences

3. A supportive administration that views the team-at-a-distance teaching approach as fulfilling a larger need ( recruitment and retention)

4. Course content that is inherently broad-scoped and multi- or inter- disciplinary

5. Instructors that agree that their diverse backgrounds and experiences add value to the course 
6. Energetic instructors who are motivated to use the course to attract new students

7. Stated course goal to promote knowledge of the engineering profession

If even a few of these realities change, the team-at-a-distance teaching approach will not be as compelling. To pursue or not to purse team-teaching is a certainly a situationally dependent question.

\section{Course Evolution: Where to from here?}

Our teaching truly becomes scholarly when we accept that our work as teachers is never complete. As noted by Dederichs, Karlshoj and Hertz, "More changes will follow. Planning and carrying out such a [team taught] course should be considered as a work in progress." 15

Our student surveys, course evaluations, individual and collective reflections have given us some ideas for improving the course. A list of improvements we are exploring is provided.

1. Provide more hands-on experiences. Experiment with the notion of "virtual labs".

2. Provide additional learner-centered activities- case studies in engineering ethics or design.

3. Archive guest lecturers presentations for reuse or use with case studies.

4. Provide more discussion based activities (as opposed to lecture) on textbook chapters.

5. Provide more peer-to-peer learning opportunities- online discussion boards, group based final project.

6. Place more emphasis (above what is in the text) on the Design Process- provide a design based exercise along with the text chapter.

\section{References}

1. Anthony A, Ramasubramanian S, Russill C, Dumas, J. Case Study Effectiveness in a Team Teaching and General Education Environment. Journal of General Education. 2003; 52(3):175-198.

2. Beavers H, DeTurck D. Shall We Dance? Team Teaching and The Harmony of Collaboration. University of Pennsylvania Almanac. 2000; 46(30).

3. Fauvel A, Miller L, Lane P, Farris J. Reflections on an Interdisciplinary, Community-Based, Team-Taught Adventure. J Cont High Educ. 2010; 58:40-46. 
4. Gardener S A, Southerland S A. Interdisciplinary Teaching? It Only Takes Talent, Time and Treasure. The English Journal. 1997; 86(7):30-36.

5. George, M A, Davis-Wiley, P. Team Teaching a Graduate Course. Case Study: A Clinical Research Course. College Teaching. 2000; 48(2):75-80.

6. Schlosberg, D, Sisk, T. The Environmental Science/Policy Interface: Crossing Disciplinary Boundaries with a Team-Teaching Approach. Political Science and Politics. 2000; 33(1);75-79.

7. Coffey, H. Team Teaching. Learn North Carolina. 2008. Available on the web at http://www.learnnc.org/lp/ pages/4754?ref=search (accessed on 7 January 2011).

8. Palmer, Barbara. Tomorrow's Professor Msg.\#712 Professors Preach Ten Commandments of Team Teaching. Tomorrow's Professor ${ }^{\mathrm{SM}}$ Mailing List. Stanford Center for Teaching and Learning. Available on the web at http:// cgi.stanford.edu/ dept-ctl/cgi-bin/tomprof/posting.php (accessed on 14 January 2011).

9. Sharp, J J, Moore, E. Teaching Mathematics to Civil Engineers. International Journal of Mathematical Education in Science and Technology. 1977; 8(2):127-131.

10. Schneider, R, Pickett, M. Bridging Engineering and Science Teaching: A Collaborative Effort to Design Instruction for College Students. School Science and Mathematics. 2006; 106(6): 259-266.

11. McKenna, A, Yalvac, B, Light, G. The Role of Collaborative Reflection on Shaping Engineering Faculty Teaching Approaches. Journal of Engineering Education. 2009; 98(1): 17-26.

12. Lo, J, Lohani, V, Odis, G. Full Implementation of a New Format For Freshman Engineering Course at Virginia Tech. Proceedings of the 2006 ASEE Annual Conference and Exposition. 2006.

13. Lo, J, Lohani, V, Gregg, M, Odis, G. Multiple Perspectives on Implementing a Team-Teaching Model. Proceedings of the 2007 ASEE Annual Conference and Exposition. 2007.

14. Braun, D, Evans, E, Knight, R, Ruehr, T. Interdisciplinary Team Teaching: Lessons for Engineering Instructors From a Capstone Course in Environmental Studies. Proceedings of the 2007 ASEE Annual Conference and Exposition. 2007.

15 Dederichs, A, Karlshoj, J, Hertz, K. Multidisciplinary Teaching: Engineering Course in Advanced Building Design. Journal of Professional Issues in Engineering Education and Practice. ASCE. 2011; 12-19.

16. Caro, P, Mclean, M, Browning, E, Hains, A. The Use of Distance Education in a Collaborative Course in Early Childhood Special Education. Teacher Education and Special Education. 2002; 25(4): 333-341.

17. Hastie, M, Hung, I, Chen, N, Kinshuk. A Blended Synchronous Learning Model for Educational International Collaboration. Innovations in Education and Teaching International. 2010; 47(1): 9-24.

18. Rutz, E, Hajek, B. Collaborative Distance Learning Using Interactive Video: Lessons Learned from the University of Cincinnati/ Ohio State University Experience. Proceedings of the Annual Conference on Distance Teaching and Learning. 1998; 315-320.

19. Utah State University Regional Campus and Distance Education. 2011. Available on the web at http://(accessed 15 January 2011).

20. Stewardson, G, Hailey, C, Wheeler, P, Walker, W. Work in Progress-Improving the Freshman Engineering Experience. Proceedings of the 34th ASEE/IEEE Frontiers in Education Conference. 2004.

21. Oakes, W, Leone, L. Gunn, C. Engineering Your Future. St. Louis: Great Lakes Press Inc.; 2009. 
22. Fang, N, Stewardson, G. Improving Engineering Laboratory Experience Through Computer Simulations and Cooperative Learning. Proceedings of the 2007 ASEE Annual Conference and Exposition. 2007.

23. Email correspondence with Dr. Christine Hailey, co-author of reference 20. 15 January 2011.

24. Knowles, M, Holton, E, Swanson, R. The Adult Learner. 6th ed. Boston: Elsevier Inc.; 2005.

25. Estell, J, Reid, K, Laird L. Cheeseburger, Fries and a Coke: Its About the Presentation. Proceedings of the 2010 ASEE Annual Conference and Exposition. 2010. 